\title{
Evaluation of In Vitro Synergistic Activities of Some Antibiotic Combinations Containing Colistin, Meropenem, Vancomycin, and Minocycline Against Oxacillinase-48 Carbapenemase-producing Klebsiella pneumoniae
}

Oksasilinaz-48 Karbapenemaz Üreten Klebsiella pneumoniae Izolatlarına Karşı Kolistin, Meropenem, Vankomisin ve Minosiklin Içeren Bazı Antibiyotik Kombinasyonlarıın In Vitro Sinerjistik Aktivitelerinin Değerlendirilmesi

\author{
(D) Ahmet SERTÇELIK ${ }^{1}$, (D) Irmak BARAN², (D) Esragül AKINCI ${ }^{3}$, (D) Sümeyye KAZANCIOĞLU³ , (D) Hürrem BODUR ${ }^{3}$ \\ ${ }_{1}^{1}$ Hacettepe University Faculty of Medicine, Department of Public Health, Subdivision of Epidemiology, Ankara, Turkey \\ ${ }^{2}$ Karadeniz Technical University Faculty of Medicine, Department of Medical Microbiology, Trabzon, Turkey \\ ${ }^{3}$ Ankara Bilkent City Hospital, Clinic of Infectious Diseases and Clinical Microbiology, Ankara, Turkey
}

\section{Abstract}

Introduction: Infection with carbapenem-resistant bacteria, such as Klebsiella pneumoniae, is a major issue due to a global shortage of antibiotic options. Moreover, due to concerns about emerging resistance and toxicity, as well as the potential synergistic effects, antibiotic combinations are preferred for carbapenem-resistant bacteria. In comparison with other carbapenemases, data on synergy tests for oxacillinase-48 (0XA-48) carbapenemase-producing K. pneumoniae are scarce. We aimed to evaluate the synergistic effects of colistin-meropenem, colistin-vancomycin, colistin-minocycline, and meropenem-minocycline combinations on OXA-48 carbapenemase-producing K. pneumoniae.

Materials and Methods: In a previous study, clonal analysis of ertapenem-resistant K. pneumoniae strains collected between May 2012 and April 2013 was performed using the repetitive element palindromic-polymerase chain reaction (Rep-PCR), and a multiplex PCR was applied to detect carbapenemase genes. From each clone, a representative isolate containing only OXA-48 carbapenemase genes was selected. Further, the broth microdilution method was used to determine the minimum inhibitor concentrations of the antimicrobials under study. Between 0ctober 2018 and March 2019, the antibiotic synergism of colistin-meropenem, colistin-vancomycin, colistin-minocycline, and meropenem-minocycline combinations was investigated using the checkerboard method against the selected strains.

Results: Oxacillinase-48-carbapenemase-producing $14 \mathrm{~K}$. pneumoniae strains from various clones were all resistant to colistin. Three of the strains were intermediate, whereas the others were meropenem-resistant. Five strains were found to be susceptible to minocycline, whereas the remaining strains were found to be intermediate. Moreover, the highest synergy was between meropenem and minocycline, which was seen in seven (50\%) of the strains. Colistin-minocycline, colistin-meropenem, and colistin-vancomycin combinations were found to have a synergistic interaction in five (35.7\%), four (28.6\%), and three (21.4\%) strains, respectively. Further, there was no evidence of antagonistic interaction.

Conclusion: Although all antibiotic combinations studied had a synergistic interaction, minocycline-based combinations had a more promising outcome in clinical trials.

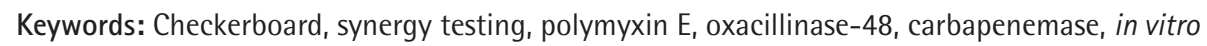

Cite this article as: Sertçelik A, Baran I, Akıncı E, Kazancıoğlu S, Bodur H. Evaluation of In Vitro Synergistic Activities of Some Antibiotic Combinations Containing Colistin, Meropenem, Vancomycin, and Minocycline Against Oxacillinase-48 Carbapenemase-producing Klebsiella pneumoniae. Mediterr J Infect Microb Antimicrob. 2021;10:57. 
Giriş: Klebsiella pneumoniae gibi karbapenem dirençli bakterilerle gelişen enfeksiyonlar antibiyotik seçeneklerinin kısıtlı olması nedeniyle tüm dünyada önemli bir sorundur. Direnç gelişme ve toksisite endişeleri ve olası sinerjistik etkilerinden faydalanmak için karbapenem dirençli bakterilerin tedavisinde antibiyotik kombinasyonları tercih edilmektedir. Diğer karbapenemazlarla karşılaştırıldığında oksasilinaz-48 (OXA-48) karbapenemaz üreten $K$. pneumoniae için sinerji verisi yetersizdir. Kolistin-meropenem, kolistin-vankomisin, kolistin-minosiklin ve meropenem-minosiklin kombinasyonlarının OXA-48 karbapenemaz üreten $K$. pneumoniae üstündeki sinerjistik etkilerinin değerlendirilmesi hedeflenmiş̧ir.

Gereç ve Yöntem: Daha önce yapılan bir çalışma kapsamında, Mayıs 2012-Nisan 2013 arasında toplanan ertapenem dirençli K. pneumoniae suşlarının klonal analizleri "tekrarlayan element palindromik-polimeraz zincir reaksiyonu" (Rep-PZR) ile, karbapenemaz genlerinin tayini ise bir multipleks PZR ile yapılmıştır. Sadece OXA-48 karbapenemaz geni içeren suşlardan her klondan birer tane olacak şekilde bir örnek seçilmiştir. Çalışılan antimikrobiyaller için minimum inhibitör konsantrasyonlar sıvı mikrodilüsyon yöntemiyle belirlenmiştir. Seçilen suşlara karşı kolistin-meropenem, kolistin-vankomisin, kolistin-minosiklin ve meropenem-minosiklin kombinasyonlarının sinerjistik etkileri dama tahtası yöntemiyle Ekim 2018-Mart 2019 arasında araştırılmıştır.

Bulgular: Farklı klonlara ait on dört OXA-48 karbapenemaz üreten K. pneumoniae suşunun tamamı kolistine dirençliydi. Üç suş meropeneme orta duyarlıyken diğerleri duyarlıydı. Beş suş minosikline duyarlıyken diğer suşlar orta duyarlıydı. En yüksek sinerji, yedi (\%50) suşta meropenem ve minosiklin arasında bulundu. Kolistin-minosiklin, kolistin-meropenem ve kolistin-vankomisin kombinasyonları için sinerjistik etkileşim sırasıyla beş $(\% 35,7)$, dört $(\% 28,6)$ ve üç $(\% 21,4)$ suşta saptandı. Kombinasyonların hiçbirinde antagonistik etkileşim gözlenmedi.

Sonuç: Çalışılan bütün antibiyotik kombinasyonlarda sinerjistik etkileşim saptansa da minosiklin temelli kombinasyonların klinik çalışmalar için cesaretlendiren ve umut vadeden sonuçları vardır.

Anahtar Kelimeler: Dama tahtası, sinerji testi, polimiksin E, oksasilinaz-48, karbapenemaz, in vitro

\section{Introduction}

Infection with resistant bacteria is a major global issue today, especially in our country, Turkey ${ }^{[1,2]}$. Klebsiella pneumoniae is one of the most common infectious agents found ${ }^{[3,4]}$. Due to its prevalence and high antimicrobial resistance rates, $K$. pneumoniae is accepted as one of the ESKAPE pathogen that is an acronym forming the names of six highly virulent and antibiotic resistant bacterial pathogens by the Infectious Diseases Society of America ${ }^{[5]}$.

Until development of the extended-spectrum beta-lactamase $(E S B L)$, carbapenems were the main and, for the most part, the only beta-lactam option for Klebsiella pneumoniae. Upon getting carbapenem resistance, almost all beta-lactam options are lost, leaving only a few efficient antimicrobial options, such as polymyxins, tigecycline, fosfomycin, and aminoglycosides ${ }^{[6]}$. Because of their pharmacokinetic properties, polymyxins, tigecycline, and aminoglycosides administered intravenously may not be convenient in the treatment of severe infections, such as bloodstream infections and pneumonia ${ }^{[7,8]}$. In some studies on hospitalized patients, carbapenem-resistant $K$. pneumoniae was found to be associated with increased mortality, and patients infected with carbapenem-resistant K. pneumoniae stayed longer in the intensive care units (ICUs) ${ }^{[9-11]}$. Antibiotic combinations are preferred not only because monotherapy options have inappropriate pharmacokinetics but also to prevent emerging resistance, reduce toxic effects, and benefit from the synergistic effects of combined antibiotics ${ }^{[6,7,12]}$. Using antibiotic combinations, especially for bloodstream infections, resulted in better outcomes ${ }^{[11]}$. Generally, combinations of colistin, carbapenems, tigecycline, fosfomycin, aminoglycosides, minocycline, and rifampicin have been studied in the previous literature ${ }^{[2,7,12-14]}$.

Carbapenem resistance can occur through a combination of mechanisms, such as the ESBL production plus porin loss or through the production of carbapenemases, such as Ambler class A carbapenemases [Klebsiella pneumoniae carbapenemases (KPC), etc.], class B carbapenemases (NDM, VIM, SIM, etc.), and class D carbapenemases [oxacillinase-48 (OXA-48), etc.] ${ }^{[2]}$. Oxacillinase-48 carbapenemase was detected for the first time in our country and the world in 2001. It has spread throughout the world, particularly in North Africa, India, and the majority of the European countries ${ }^{[15,16]}$. In Turkey, OXA-48 carbapenemase is still the most prevalent carbapenemase ${ }^{[1,2]}$.

The majority of the studies focused on KPC and metallo-betalactamase-producing microorganisms. For OXA-48-producing microorganisms, there was a lack of in vitro studies in Turkey and the rest of the world. In our study, using the checkerboard method, we aimed to detect the potential in vitro synergistic effect of colistin-meropenem, colistin-vancomycin, colistinminocycline, and meropenem-minocycline combinations against OXA-48-producing K. pneumoniae strains.

\section{Materials and Methods}

This study was carried out in the Clinical Microbiology Laboratory of Ankara Numune Training and Research Hospital, a 1200-bed tertiary care hospital and referral center with surgical and medical ICUs that served patients from Ankara and the surrounding cities. Shortly after the completion of this study, Ankara Numune Training and Research Hospital was dissolved, and the remaining units were transferred to Ankara Bilkent City Hospital in May 2019. 


\section{Isolates}

The isolates for this study were selected from a collection of ertapenem-resistant $K$. pneumoniae strains obtained from routine ICU surveillance cultures and clinical samples of patients admitted to the ICU for at least 48 hours between May 2012 and April 2013. At the time of first isolation, the collected bacterial strains were identified using conventional biochemical reactionbased tests and the VITEK II ${ }^{\circledR}$ system (bioMérieux, Marcy l'Etoile, France). Additionally, the identification results were confirmed using the matrix-assisted laser desorption ionization-time of flight (MALDI-TOF) method via MALDI Biotyper ${ }^{\circledR}$ (Microflex LT., Bruker Daltonics Inc., Germany). Moreover, the VITEK II ${ }^{\circledR}$ system (bioMérieux) was used to analyze antibiotic susceptibility tests using VITEK GN AST cards. Colistin susceptibility was also determined using the broth microdilution method, as recommended by the European Committee on Antimicrobial Susceptibility Testing (EUCAST) ${ }^{[17]}$. Ertapenem-resistant $K$. pneumoniae strains were tested for carbapenemase genes, and their genetic relationships were studied as part of a previously unpublished study. The strains had MIC values of meropenem above the screening cutoff value for carbapenemase-producing Enterobacteriaceae $(>0.125 \mu \mathrm{g} / \mathrm{ml})^{[18]}$. Previously, K. pneumoniae strains were cloned using the repetitive element palindromicpolymerase chain reaction (Rep-PCR) DiversiLab ${ }^{\circledR}$ (bioMérieux). The Pearson correlation coefficient was used to calculate distance matrices, and the unweighted pair group method with arithmetic averages was used to create dendrograms of the isolates. All isolates with Rep-PCR patterns that had a similarity index of $>95 \%$ were grouped together in the same cluster.

To detect carbapenemase genes, a multiplex PCR (hyplex ${ }^{\circledR}$ SuperBug ID, Amplex, Germany) was used according to the manufacturer's recommendations. This system can identify

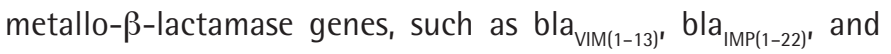
bla $_{\text {NDM- }}$; oxacillinase genes, such as bla ${ }_{\text {OXA-48 }}$-like encoding genes (including $\mathrm{bla}_{\text {OXA-162' OXA-181, OXA-204' }}$ and $\mathrm{bla}_{\text {OXA-244 }}$ ); and all variants of bla $\mathrm{KPC(1-10)}$ genes.

Isolates were kept at $-80^{\circ} \mathrm{C}$ until the day of synergy testing. Among the isolates containing only bla ${ }_{0 \times A-48}$-like genes, one representative isolate from each clone was selected for synergy testing. Before beginning the studies, the selected isolates were thawed and subcultured twice in 5\% sheep blood agar.

\section{Synergy Testing with the Checkerboard Method}

Between October 2018 and March 2019, the synergistic activities of four antibiotic combinations were evaluated. Before starting the checkerboard tests for meropenem trihydrate (SigmaAldrich, St. Louis, M0), vancomycin hydrochloride (SigmaAldrich), minocycline hydrochloride (Sigma-Aldrich), and colistin sulfate (Sigma-Aldrich), the minimum inhibitory concentration (MIC) values were checked using the broth microdilution method to determine the necessary MIC ranges that would be used in checkerboard tests. Further, all of the studied antibiotics were diluted with Mueller-Hinton broth (Sigma-Aldrich). After an 18-24-hour incubation period, MIC values were recorded. The susceptibilities of the studied strains to meropenem and colistin were determined using EUCAST breakpoints ${ }^{[17]}$, and minocycline was determined using the Clinical and Laboratory Standards Institute breakpoints due to a lack of recommendation in EUCAST ${ }^{[19]}$. Because $K$. pneumoniae was intrinsically resistant to vancomycin, vancomycin susceptibility was not considered. Except for vancomycin, the $\mathrm{MIC}_{50}$ and $\mathrm{MIC}_{90}$ values of the antimicrobials were calculated.

Panels of 96-well microtiter plates (Isolab, Ankara, Turkey) were prepared based on the MIC ranges found. The dilution intervals were found to be 4-8 times higher and 1/8-1/16 below the MIC values. In colistin-based combinations, the concentration ranges for colistin, meropenem, vancomycin, and minocycline were 32$0.03125 \mu \mathrm{g} / \mathrm{ml}, 8-0.125 \mu \mathrm{g} / \mathrm{ml}, 512-8 \mu \mathrm{g} / \mathrm{ml}$, and $16-0.25 \mu \mathrm{g} / \mathrm{ml}$, respectively, and in meropenem-minocycline combinations, the concentration range for meropenem was $32-0.03125 \mu \mathrm{g} / \mathrm{ml}$ and minocycline was $16-0.25 \mu \mathrm{g} / \mathrm{ml}$. The antibiotic solutions were distributed to microplates beforehand, and the microplates were stored at $-80{ }^{\circ} \mathrm{C}$ until inoculation. We used these microplates for two weeks with no discernible decrease in the effectiveness of the antibiotics. The checkerboard method was implemented as recommended by the Clinical Microbiology Procedures Handbook ${ }^{[20]}$.

The inoculum was prepared for the final microorganism at a density of $3-5 \times 10^{5} \mathrm{CFU} / \mathrm{ml}$ from the stored strains. All of the wells were inoculated, except for the sterility control well. From the control well, a purity plate and counting plate (5\% sheep blood agar plate) were prepared. All of the microplates and agar plates were incubated in ambient air for $18-24$ hours at $35^{\circ} \mathrm{C}$. Moreover, Escherichia coli ATCC 25922 and Staphylococcus aureus ATCC 25923 were used as quality control strains.

The fractional inhibitory concentration (FIC) of each antibiotic in each combination was determined. For the calculations, the following formulas were used: $\mathrm{FICx}=\mathrm{MIC}$ of antibiotic $\mathrm{X}$ in combination/MIC of antibiotic $\mathrm{X}$ alone and $\mathrm{FICy}=\mathrm{MIC}$ of antibiotic $Y$ in combination/MIC of antibiotic $Y$ alone. The FIC index ( $\mathrm{FICl}$ ) was calculated by adding $\mathrm{FICx}$ and $\mathrm{FICy}$ together. $\mathrm{FICls}$ were interpreted as a synergistic interaction if $\mathrm{FICl} \leq 0.5$, an additive interaction if $0.5<\mathrm{FICl}<1$, an indifferent interaction if $1 \leq \mathrm{FICl} \leq 4$, and an antagonistic interaction if $\mathrm{FICl}>4$. 


\section{Results}

All 68 isolates included in the previous study, the results of which were not published, contained the bla $\mathrm{OXA}-48$-like encoding genes. As a result of the clone analysis, a total of 14 clones were detected. The 14 strains from these 14 clones were isolated from the rectal swabs and urine, wound, and tracheal aspirate samples. The rectal swab was the most common (57.1\%) sample from which the strains were isolated (Table 1).

All of the studied strains were also resistant to colistin. Three of the strains were intermediate, whereas the others were meropenem-resistant. Five strains were found to be susceptible to minocycline, whereas the remaining strains were found to be intermediate. Table 2 shows the $\mathrm{MIC}_{50^{\prime}} \mathrm{MIC}_{90^{\prime}}$ and $\mathrm{MIC}$ range for colistin, meropenem, and minocycline. Because K. pneumoniae is intrinsically resistant to vancomycin, $\mathrm{MIC}_{50^{\prime}} \mathrm{MIC}_{90^{\prime}}$ and $\mathrm{MIC}$ ranges for vancomycin were not given.

Table 3 displays the results of the synergy tests. Moreover, there were no antagonistic interactions in any of the combinations. In all strains studied, synergistic or additive interaction was detected in meropenem-minocycline and colistin-minocycline combinations. Further, meropenem-minocycline combinations demonstrated the highest synergy $(50 \%)$. The synergy rates of

Table 1. Distribution of clinical samples from which the strains were obtained

\begin{tabular}{lll}
\hline Clinical samples & Number $(\mathbf{n})$ & Percentage (\%) \\
\hline Rectal swab & 8 & 57.1 \\
\hline Urine & 3 & 21.1 \\
\hline Wound & 2 & 14.3 \\
\hline Tracheal aspirate & 1 & 7.1 \\
\hline Total & 14 & 100 \\
\hline
\end{tabular}

other antibiotic combinations were determined to be $35.7 \%$ for colistin-minocycline, $28.6 \%$ for colistin-meropenem, and 21.4\% for colistin-vancomycin.

Table 4 shows the $\mathrm{FICl}$ values of the antibiotic combinations as well as the distribution of interaction types.

\section{Discussion}

Carbapenems are effective antibiotics against carbapenemresistant $K$. pneumoniae due to their pharmacokinetic properties and efficacy. However, due to increasing carbapenem resistance, alternative treatment strategies have been required. For our country, OXA-48 carbapenemase production is the most important carbapenem resistance mechanism, and it is becoming more important in other countries ${ }^{[1,2]}$. Due to a lack of investigations, treatment options for 0XA-48 carbapenemases have remained unclear and insufficient when compared to other carbapenemases ${ }^{[3]}$. Combined antibiotic therapies, especially for bloodstream infections, have also been shown to reduce mortality ${ }^{[1,21]}$. As a result, we investigated the effects of various antibiotic combinations against OXA-48-carbapenemaseproducing K. pneumoniae. None of the studied combinations exhibited antagonistic interactions. Synergistic and additive interaction rates were high in all combinations, especially for minocycline-based combinations.

Colistin was once a very effective antimicrobial against carbapenem-resistant Enterobacteriaceae. Colistin-based treatment options were investigated and clinically used more frequently than any other options ${ }^{[3,4,12]}$. Contrarily, colistin resistance rates have recently increased ${ }^{[3]}$. According to the susceptibility testing results, the strains considered susceptible may have heteroresistance to colistin. In a study involving three $K$. pneumoniae strains, colistin-resistant subpopulations were detected, regardless of the colistin MIC values ${ }^{[22]}$. The antibiotic

Table 2. The minimum inhibitory concentration (MIC), the minimum inhibitory concentration 50 ( $\mathrm{MIC}_{50}$ ), the $\mathrm{MIC}_{90}$ values, and the MIC range for minocycline, colistin, and meropenem $(n=14)$

\begin{tabular}{llll} 
& $\mathrm{MIC}_{50}(\mu \mathrm{g} / \mathrm{ml})$ & $\mathrm{MIC}_{90}(\mu \mathrm{g} / \mathrm{ml})$ & $\mathrm{MIC} \mathrm{range}(\mu \mathrm{g} / \mathrm{ml})$ \\
\hline Minocycline & 4 & 8 & $4-8$ \\
\hline Colistin & 4 & 16 & $4-32$ \\
\hline Meropenem & 1 & 8 & $0.25-8$ \\
\hline
\end{tabular}

MIC: Minimum inhibitory concentration

Table 3. The synergy test results of antimicrobial combinations, $\mathbf{n}\left(\% \%^{*}\right)$

\begin{tabular}{lllll}
\hline Combination & Synergism & Additive effect & Indifferent effect & Total \\
\hline Colistin-meropenem & $4(28.6)$ & $7(50.0)$ & $3(21.4)$ & $14(100)$ \\
\hline Colistin-minocycline & $5(35.7)$ & $9(64.3)$ & - & $14(100)$ \\
\hline Meropenem-minocycline & $7(50.0)$ & $7(50.0)$ & - & $14(100)$ \\
\hline Colistin-vancomycin & $3(21.4)$ & $10(71.4)$ & $1(7.1)$ & $14(100)$ \\
\hline
\end{tabular}

*Row percentages 
Table 4. Distribution of the fractional inhibitory concentration index and antimicrobial interaction type in antibiotic combinations

\begin{tabular}{|c|c|c|c|c|c|c|c|c|}
\hline \multirow[t]{2}{*}{ Strain number } & \multicolumn{2}{|c|}{ Colistin-meropenem } & \multicolumn{2}{|c|}{ Colistin-minocycline } & \multicolumn{2}{|c|}{ Meropenem-minocycline } & \multicolumn{2}{|c|}{ Colistin-vancomycin } \\
\hline & $\mathrm{FICl}$ & Int & $\mathrm{FICl}$ & Int & $\mathrm{FICl}$ & Int & $\mathrm{FICl}$ & Int \\
\hline 1 & 1.00 & I & 0.63 & A & 0.75 & A & 0.51 & A \\
\hline 2 & 1.13 & 1 & 0.53 & A & 0.38 & $\mathrm{~S}$ & 0.5 & $\mathrm{~S}$ \\
\hline 3 & 0.53 & A & 0.32 & $\mathrm{~S}$ & 0.5 & $\mathrm{~S}$ & 0.63 & A \\
\hline 4 & 0.63 & A & 0.5 & $\mathrm{~S}$ & 0.28 & $\mathrm{~S}$ & 0.56 & A \\
\hline 5 & 0.53 & $A$ & 0.53 & $A$ & 0.56 & $A$ & 0.53 & $A$ \\
\hline 6 & 0.63 & $A$ & 0.5 & $\mathrm{~S}$ & 0.75 & A & 0.51 & A \\
\hline 7 & 1.00 & 1 & 0.53 & A & 0.75 & A & 0.52 & A \\
\hline 8 & 0.53 & $A$ & 0.5 & $\mathrm{~S}$ & 0.75 & A & 0.5 & $\mathrm{~S}$ \\
\hline 9 & 0.32 & $S$ & 0.53 & A & 0.5 & $S$ & 0.63 & $A$ \\
\hline 10 & 0.27 & $S$ & 0.28 & $\mathrm{~S}$ & 0.38 & $S$ & 0.5 & $S$ \\
\hline 11 & 0.63 & A & 0.53 & A & 0.5 & $S$ & 0.53 & A \\
\hline 12 & 0.13 & $\mathrm{~S}$ & 0.53 & $A$ & 0.75 & $A$ & 1.00 & 1 \\
\hline 13 & 0.63 & $A$ & 0.56 & $A$ & 0.75 & A & 0.53 & $A$ \\
\hline 14 & 0.38 & $S$ & 0.56 & $A$ & 0.5 & $S$ & 0.53 & $A$ \\
\hline
\end{tabular}

FICI: Fractional inhibitory concentration index, Int: Interaction type, S: Synergy, A: Additive effect, I: Indifferent effect

susceptibility testing technique also interferes with the results. In our study, all of the strains studied were resistant to colistin. It was surprising because colistin resistance rates were initially detected lower due to the use of an automated system rather than the broth microdilution method ${ }^{[23]}$. So, a combination strategy is essential for colistin-based therapies.

In a study investigating the synergy rate of colistin and meropenem, 50 carbapenem-resistant $K$. pneumoniae were studied with the checkerboard and time-kill assay. The majority of the 50 strains produced OXA-48 carbapenemases. Higher synergy rates were detected with the time-kill assay. Colistinresistant and susceptible strains had synergy rates of 50\% and $45.2 \%$, respectively ${ }^{[4]}$. Moreover, the synergy rate of the colistin-meropenem combination was found to be $28.6 \%$. Similarly, Gaibani et al. ${ }^{[7]}$ reported that the synergy rate for the colistin-meropenem combination was three out of eight among colistin-resistant $K$. pneumoniae. Different resistance mechanisms and different techniques can yield varying results for in vitro studies. In an observational study of bloodstream infections caused by OXA-48-producing Enterobacteriaceae from Turkey, colistin-based dual combinations (carbapenems, aminoglycosides, cephalosporins) had no difference in clinical outcomes $(p>0.05)^{[24]}$. In another study, carbapenem-containing antibiotic combinations outperformed non-carbapenemcontaining antibiotic combinations $(p=0.04$; Odds ratio: 5.15 ; 95\% confidence interval: $1.1-24.5)^{[25]}$.

Vancomycin is a big molecule for penetration of the outer membrane of Gram-negative microorganisms. So, Gramnegative bacilli, such as Klebsiella spp. and Acinetobacter spp., are intrinsically resistant to vancomycin. Colistin is a cationic detergent that disrupts the outer membrane. A previous study discovered that when colistin was combined with vancomycin, vancomycin may be effective against Acinetobacters whose outer membrane has been disrupted by colistin. According to the same study, the surfaces of the colistin-exposed Acinetobacters had pits and increased topographic variabilities ${ }^{[26]}$. To the best of our knowledge, the colistin-vancomycin combination has not been tested on Klebsiella spp. The purpose of this study was to investigate the effects of the colistin-vancomycin combination on K. pneumoniae based on its effects on Acinetobacters, and nearly one in five of the studied strains showed synergistic interaction with colistin-vancomycin combination. Similarly, in a study on colistin-resistant Enterobacteriaceae (10 of 20 strains were $K$. pneumoniae), the synergy rate of colistin-vancomycin was found to be $25 \%{ }^{[12]}$.

Minocycline is a derivative of tetracycline. Its tissue penetration is superior to that of other tetracyclines ${ }^{[27]}$. Minocycline is used to treat pneumonia and urinary tract infections with carbapenem-resistant Acinetobacter baumannii. Minocycline can be administered intravenously or orally. In this manner inpatients who have been discharged can be treated with minocycline. However, there is no reliable advice for minocycline monotherapy in carbapenem-resistant $K$. pneumoniae as much as carbapenem-resistant $A$. baumanni ${ }^{[8]}$. In our study, five of the studied strains were susceptible to minocycline, whereas the others were intermediate. It was shown that polymyxin B facilitated the passing of minocycline to the cytosol in a study on Acinetobacters ${ }^{[28]}$. With a similar effect expectation for $K$. 
pneumoniae, we studied colistin (polymyxin E)-minocycline and meropenem-minocycline combinations. These combinations had synergy rates of $35.7 \%$ and $50 \%$, respectively. Using the time-kill assay, Huang et al. ${ }^{[13]}$ investigated the synergy between polymyxin B and minocycline among KPC-producing $K$. pneumoniae. On the $24^{\text {th }}$ hour, the synergy rate was detected to be $50 \%$. In a study using inkjet printer-based technology, the synergy rates for colistin-minocycline were 30\% and 10\% for meropenem-minocycline among 10 carbapenemresistant Enterobacteriaceae strains (five of which were K. pneumoniae ${ }^{[29]}$.

There are some limitations to this study. The isolates were obtained from a single center in a small number. With the clonal analysis, internal validity was aimed to be achieved with the least number of samples. However, external validity could not be asserted. Resistance mechanisms of antibiotics other than carbapenem (minocycline, vancomycin, and colistin) could not be evaluated. Other methods for synergy tests, such as the timekill assay and gradient strip test, were not applied to support the results of the checkerboard method.

\section{Conclusion}

Today, it is well understood that combined antibiotic therapies are necessary for infections caused by carbapenem-resistant $K$. pneumoniae. Combined therapy options are limited, and especially for OXA-48-carbapenemase-producing microorganisms, efficient combinations are required. The synergistic effects of colistin-meropenem, colistin-vancomycin, colistinminocycline, and meropenem-minocycline combinations with the checkerboard method were investigated. All of the studied combinations yielded promising results, but with the exception of colistin-meropenem combinations, clinical studies on antibiotic combinations we examined were insufficient. As a result, clinical studies are needed for all antibiotic combinations. With their high synergy rates and proper pharmacokinetic features, minocycline-based combinations, in particular, are promising for improved clinical outcomes.

\section{Ethics}

Ethics Committee Approval: No ethical committee's approval was required.

Informed Consent: This study was only about microorganisms.

Peer-review: Externally and internally peer-reviewed.

\section{Authorship Contributions}

Concept: A.S., I.B., E.A., H.B., Design: A.S., I.B., E.A., Data Collection or Processing: A.S., I.B., Analysis or Interpretation: A.S., I.B., Literature Search: A.S., I.B., S.K., Writing: A.S., I.B., E.A., S.K., H.B.
Conflict of Interest: No conflict of interest was declared by the authors.

Financial Disclosure: The materials used in this study were funded by the Infectious Diseases and Clinical Microbiology Specialty Society of Turkey for a previous study.

\section{References}

1. Girmenia C, Serrao A, Canichella M. Epidemiology of Carbapenem Resistant Klebsiella pneumoniae Infections in Mediterranean Countries. Mediterr J Hematol Infect Dis. 2016;8:e2016032.

2. Evren $\mathrm{E}_{1}$ Azap OK, Çolakoğlu Ş, Arslan H. In vitro activity of fosfomycin in combination with imipenem, meropenem, colistin and tigecycline against OXA 48-positive Klebsiella pneumoniae strains. Diagn Microbiol Infect Dis. 2013;76:335-8.

3. Bedenič $B, C a r H$, Slačanac $D$, Sviben $M$, Čačič $M$, Lukič-Grlič $A$, Benčič $A$, Šijak D, Tripkovič $M$, Beader N. In vitro synergy and postantibiotic effect of colistin combinations with meropenem and vancomycin against Enterobacteriaceae with multiple carbapenem resistance mechanisms. J Infect Chemother. 2018;24:1016-9.

4. Laishram S, Anandan S, Devi BY, Elakkiya M, Priyanka B, Bhuvaneshwari T, Peter JV, Subramani K, Balaji V. Determination of synergy between sulbactam, meropenem and colistin in carbapenem-resistant Klebsiella pneumoniae and Acinetobacter baumannii isolates and correlation with the molecular mechanism of resistance. J Chemother. 2016;28:297-303.

5. Boucher HW, Talbot GH, Bradley JS, Edwards JE, Gilbert D, Rice LB, Scheld M, Spellberg B, Bartlett J. Bad bugs, no drugs: no ESKAPE! An update from the Infectious Diseases Society of America. Clin Infect Dis. 2009;48:1-12.

6. Tascini C, Tagliaferri E, Giani T, Leonildi A, Flammini S, Casini B, Lewis R, Ferranti S, Rossolini GM, Menichetti F. Synergistic activity of colistin plus rifampin against colistin-resistant KPC-producing Klebsiella pneumoniae. Antimicrob Agents Chemother. 2013;57:3990-3.

7. Gaibani $\mathrm{P}$, Lombardo D, Lewis RE, Mercuri M, Bonora S, Landini MP, Ambretti $\mathrm{S}$. In vitro activity and post-antibiotic effects of colistin in combination with other antimicrobials against colistin-resistant KPC-producing Klebsiella pneumoniae bloodstream isolates. J Antimicrob Chemother. 2014;69:185665.

8. Pogue JM, Neelakanta $A$, Mynatt RP, Sharma $S$, Lephart $P$, Kaye KS Carbapenem-resistance in gram-negative bacilli and intravenous minocycline: an antimicrobial stewardship approach at the Detroit Medical Center. Clin Infect Dis. 2014;59(Suppl 6):S388-93.

9. Schwaber MJ, Klarfeld-Lidji S, Navon-Venezia S, Schwartz D, Leavitt A, Carmeli Y. Predictors of carbapenem-resistant Klebsiella pneumoniae acquisition among hospitalized adults and effect of acquisition on mortality. Antimicrob Agents Chemother. 2008;52:1028-33.

10. Patel G, Huprikar S, Factor SH, Jenkins SG, Calfee DP. Outcomes of carbapenem-resistant Klebsiella pneumoniae infection and the impact of antimicrobial and adjunctive therapies. Infect Control Hosp Epidemiol. 2008;29:1099-106.

11. Tumbarello $M$, Viale $P$, Viscoli $C$, Trecarichi EM, Tumietto $F$, Marchese $A$, Spanu T, Ambretti S, Ginocchio F, Cristini F, Losito AR, Tedeschi S, Cauda $R$, Bassetti M. Predictors of mortality in bloodstream infections caused by Klebsiella pneumoniae carbapenemase-producing $K$. pneumoniae: importance of combination therapy. Clin Infect Dis. 2012;55:943-50.

12. Brennan-Krohn T, Pironti A, Kirby JE. Synergistic Activity of ColistinContaining Combinations against Colistin-Resistant Enterobacteriaceae. Antimicrob Agents Chemother. 2018;62:e00873-18. 
13. Huang D, Yu B, Diep JK, Sharma R, Dudley M, Monteiro J, Kaye KS, Pogue JM, Abboud CS, Rao GG. In Vitro Assessment of Combined Polymyxin B and Minocycline Therapy against Klebsiella pneumoniae Carbapenemase (KPC)Producing K. pneumoniae. Antimicrob Agents Chemother. 2017;61:e0007317.

14. Erturk Sengel B, Altinkanat Gelmez G, Soyletir G, Korten V. In vitro synergistic activity of fosfomycin in combination with meropenem, amikacin and colistin against OXA-48 and/or NDM-producing Klebsiella pneumoniae. J Chemother. 2020;32:237-43.

15. Lee CR, Lee JH, Park KS, Kim YB, Jeong BC, Lee SH. Global Dissemination of Carbapenemase-Producing Klebsiella pneumoniae: Epidemiology, Genetic Context, Treatment Options, and Detection Methods. Front Microbiol. 2016;7:895

16. Poirel L, Héritier C, Tolün V, Nordmann P. Emergence of oxacillinasemediated resistance to imipenem in Klebsiella pneumoniae. Antimicrob Agents Chemother. 2004;48:15-22.

17. Breakpoint tables for interpretation of MICs and zone diameters. Version 9.0 ed: The European Committee on Antimicrobial Susceptibility Testing; 2019.

18. Christian G. Giske LM-M, Rafael Cantón, Stefania Stefani, Youri Glupczynski, Patrice Nordmann, Mandy Wootton, Vivi Miriagou, Gunnar Skov Simonsen, Helena Zemlickova, James Cohen-Stuart, Marek Gniadkowski. EUCAST guidelines for detection of resistance mechanisms and specific resistances of clinical and/or epidemiological importance. Vol 2: the European Committee on Antimicrobial Susceptibility Testing; 2017:4-9.

19. Clinical and Laboratory Standards Institute (CLSI) (2014). Performance Standards for Antimicrobial Susceptibility Testing; Twenty-Fourth Informational Supplement. CLSI Document M100-S24, Wayne, 34.

20. Moody J. Synergism Testing: Broth Microdilution Checkerboard and Broth Macrodilution Methods. In: Garcia LS (ed). Clinical Microbiology Procedures Handbook. $3^{\text {rd }}$ Edition ed. Washington, DC: ASM Press; 2010:140-62.

21. Vardakas KZ, Athanassaki F, Pitiriga V, Falagas ME. Clinical relevance of in vitro synergistic activity of antibiotics for multidrug-resistant Gram- negative infections: A systematic review. J Glob Antimicrob Resist. 2019;17:250-9.

22. Vidaillac C, Benichou L, Duval RE. In vitro synergy of colistin combinations against colistin-resistant Acinetobacter baumannii, Pseudomonas aeruginosa, and Klebsiella pneumoniae isolates. Antimicrob Agents Chemother. 2012;56:4856-61.

23. Matuschek E, Åhman J, Webster C, Kahlmeter G. Antimicrobial susceptibility testing of colistin - evaluation of seven commercial MIC products against standard broth microdilution for Escherichia coli, Klebsiella pneumoniae, Pseudomonas aeruginosa, and Acinetobacter spp. Clin Microbiol Infect. 2018;24:865-70.

24. Balkan II, Aygün G, Aydın S, Mutcalı SI, Kara Z, Kuşkucu M, Midilli K, Şemen V, Aras S, Yemişen M, Mete B, Özaras R, Saltoğlu N, Tabak F, Öztürk R. Blood stream infections due to OXA-48-like carbapenemase-producing Enterobacteriaceae: treatment and survival. Int J Infect Dis. 2014;26:51-6.

25. Akova M, Daikos GL, Tzouvelekis L, Carmeli Y. Interventional strategies and current clinical experience with carbapenemase-producing Gram-negative bacteria. Clin Microbiol Infect. 2012;18:439-48.

26. Gordon NC, Png K, Wareham DW. Potent synergy and sustained bactericidal activity of a vancomycin-colistin combination versus multidrug-resistant strains of Acinetobacter baumannii. Antimicrob Agents Chemother. 2010;54:5316-22.

27. Ritchie DJ, Garavaglia-Wilson A. A review of intravenous minocycline for treatment of multidrug-resistant Acinetobacter infections. Clin Infect Dis. 2014;59(Suppl 6):S374-80.

28. Bowers DR, Cao H, Zhou J, Ledesma KR, Sun D, Lomovskaya O, Tam VH. Assessment of minocycline and polymyxin B combination against Acinetobacter baumannii. Antimicrob Agents Chemother. 2015;59:2720-5.

29. Brennan-Krohn T, Truelson KA, Smith KP, Kirby JE. Screening for synergistic activity of antimicrobial combinations against carbapenem-resistant Enterobacteriaceae using inkjet printer-based technology. J Antimicrob Chemother. 2017;72:2775-81. 